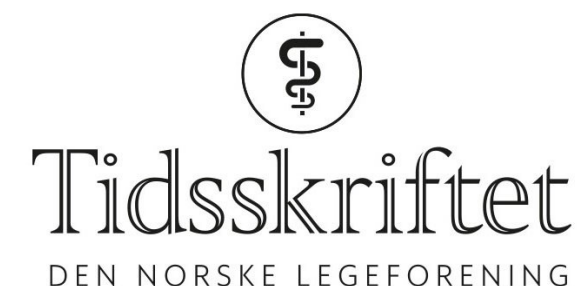

DEN NORSKE LEGEFORENING

\title{
Er arbeid sunt?
}

GJESTESKRIBENT

PÅL MOLANDER

E-post: pal.molander@stami.no

Direktør Statens arbeidsmiljøinstitutt (STAMI)

Norge er i verdenstoppen på arbeidsmiljø. Når arbeidslivet nå opplever økt endringstakt, trenger vi vel neppe å bekymre oss for dette? Alle sier jo at arbeid gir helse uansett.

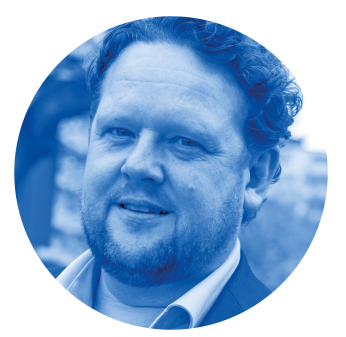

Det synes å være allment akseptert at arbeid er noe av det sunneste som finnes - at arbeid gir god helse. Det er liten tvil om at spesielt unge mennesker med mildere psykiske lidelser som er til hinder for arbeidsdeltagelse, noe som er et økende samfunnsproblem, opplever bedre helse og velvære hvis de kommer inn i en meningsfull jobb som de mestrer. Men kan vi på bakgrunn av dette generalisere at arbeid per definisjon gir bedre helse?

Man trenger ikke være spesielt oppvakt for å forstå at den generelle helsetilstanden $\mathrm{i}$ arbeidsstokken er bedre enn helsetilstanden til dem som står utenfor arbeidslivet (i samme aldersgruppe). Helsetilstand er en opplagt seleksjonsmekanisme. Allikevel er det mange, også på myndighetssiden, som legger dette til grunn for at arbeid utelukkende er bra for helsen.

Det foreligger mye kunnskap om at arbeidsmiljøeksponering kan bidra til uhelse. Det finnes til og med solid kunnskap om årsakssammenhenger mellom arbeidsmiljøforhold og sykdom - til og med død i ytterste konsekvens. Og ifølge Statistisk sentralbyrås levekårsundersøkelser oppgir nærmere $40 \%$ av dem med et sykefravær på mer enn 14 dager siste år at arbeidet helt eller delvis var årsaken til sykefraværet. Så trenger man ikke være spesielt fantasifull for å reflektere over mulige attribusjonseffekter knyttet til denne type selvrapporterte undersøkelser. Men alt kan umulig være attribusjonseffekter?

Sintef har på oppdrag fra Arbeidstilsynet anslått, i et forsiktig estimat, at det årlige tapet for samfunnet knyttet til dårlig arbeidsmiljøforhold er 30 milliarder kroner. Og da er ikke produktivitetstapet i de enkelte virksomheter regnet med. Det mangler med andre ord verken vitenskapelig kunnskap om årsakssammenhenger mellom eksponeringer i arbeid og uhelse eller om uheldige samfunns- og bedriftskonsekvenser av dette. I et slikt lys fremstår jo den oppleste sannheten om at arbeid per definisjon utelukkende er bra for 
helsen som litt underlig - selv i et land som ifølge internasjonale undersøkelser er i verdenstoppen på arbeidsmiljø.

Og i en tid hvor arbeidslivet er preget av rask omstilling og en rivende teknologiutvikling som påvirker arbeidsprosesser, arbeidsformer og arbeidsmiljøforhold, kan det være direkte kontraproduktivt for nasjonen å leve i denne naive vissheten. Det er nemlig godt belegg for å hevde at høy endringstakt kan gi økt risiko for arbeidsrelatert uhelse.

Det norske arbeidslivet skiller seg først og fremst ut på to områder. Yrkesdeltagelsen er av verdens høyeste, og vi er et høykostland hvor det stilles høye krav i arbeidet. Vi har med andre ord en mer sårbar yrkespopulasjon som det ifølge internasjonale undersøkelser stilles høyere krav til enn i de fleste andre land. I tillegg vil vi fremover være avhengige av å $\emptyset$ ke sysselsettingsgraden ytterligere gjennom inkludering og ved å heve den reelle pensjonsalderen i Norge for å kunne opprettholde dagens velferdstilbud. Og dette skal foregå midt under den fjerde industrielle revolusjon, i en stadig mer globalisert og konkurranseutsatt verden. Det er en massiv oppgave vi har foran oss.

Høye krav i arbeidet over tid er velkjent risikofaktor for uhelse, hvis ikke dette blir balansert av muligheten til å kunne ha kontroll over eget arbeid. Og nettopp på kontrolldimensjonen har vi vært strålende dyktige i norsk arbeidsliv lenge. Vi har i hovedsak et arbeidsliv hvor arbeidstakere har gode muligheter for å kunne prege egen arbeidsdag gjennom høy grad av autonomi, innenfor de rammer som er gitt av arbeidsgiver. En slik aktiv arbeidsform bidrar til jobbengasjement og gir helse. Nyere studier viser også at slike arbeidsmiljøer bidrar positivt til virksomheters resultater og produktivitet. Dette har vært et norsk

konkurransefortrinn vi bør gjøre vårt ytterste for å opprettholde i tiden fremover -gjennom alle de endringene vi sannsynligvis skal igjennom.

Og hva er legens rolle i dette? Vi trenger leger, både arbeidsmedisinere i

bedriftshelsetjenesten og andre, som har bevissthet knyttet til arbeidsmiljøets betydning for helse, sykefravær og frafall. Vi trenger dyktige leger med kunnskap om eksponeringer i arbeid og årsakssammenhenger - og ikke minst om kunnskapsbaserte forebyggende tiltak. Det er grunn til bekymring over at mange nå forbinder forebygging utelukkende med tiltak mot livsstilsykdommer, og tror at arbeid uansett er sunt. Norske virksomheter vil trenge hjelp med dette fremover når vi nå med bærekraft skal gå inn i endret og ukjent landskap.

Legenes rolle i dette bør være viktig. Dere bør derfor spre budskapet om at arbeid er sunt men kun hvis arbeidsmiljøforholdene er gode. Da vil dere gjøre nasjonen og norske virksomheter en stor tjeneste.

Publisert: 28. november 2017. Tidsskr Nor Legeforen. DOI: 10.4045/tidsskr.17.0942

(C) Tidsskrift for Den norske legeforening 2020. Lastet ned fra tidsskriftet.no 